https://doi.org/10.52058/2695-1592-2021-7(7)-119-129

\title{
Роман Лев
}

аспірант кафедри кримінального процесу та криміналістики

Університету державної фіскальної служби України

м. Iрпінь, Україна, е-mail: zxcv79@meta.ua, https://orcid.org/0000-0001-9614-3978

\section{СПОСОБИ ВЧИНЕННЯ НЕЗАКОННОГО ОБЕРНЕННЯ ЧУЖОГО МАЙНА НА СВОЮ КОРИСТЬ, ШЛЯХОМ ВИКОРИСТАННЯ СЛУЖБОВОГО СТАНОВИЩА}

Анотація. У статті досліджено одну 3 груп способів вчинення корупційних злочинів, які вчиняються службовими особами юридичних осіб публічного права, а саме: незаконне обернення чужого майна на свою користь, вчинене з використанням службового становища. Визначено поняття способу вчинення незаконного обернення чужого майна на свою користь, шляхом використання службового становища.

Вказано, що особливістю способів вчинення незаконного обернення чужого майна на свою користь, шляхом використання службового становища, $\epsilon$ корупційний характер таких протиправних діянь та предмети злочинних посягань. Також наголошено на тому, що на спосіб вчинення незаконного обернення чужого майна на свою користь, яке вчиняється службовою особою публічного права 3 використанням свого службового становища, впливають розумові здібності службової особи - злочинця, які прямо пропорційно впливають на вибір засобів щодо способу скоєння й приховування злочину. Так, для забезпечення можливості вчинення корупційного злочину даної категорії, службовій особі необхідно розробити певну технологію протиправної поведінки, яку потім можна втілити у життя особисто або групою осіб.

Здійснено класифікацію способів вчинення незаконного обернення чужого майна на свою користь шляхом використання службового становища. Окреслено форми та характерні ознаки способів вчинення злочинів даної категорії, які залежать від ряду обставин, зокрема: загального стану економіки та окремих іiї галузей; сфери господарської діяльності, де вчиняється злочин (сфера торгівлі, будівництва, вугільної галузі, сільського господарства); характеру предмета посягання; правової захищеності напрямів економічної діяльності підприємництва, установи, організації; особливостей фінансовогосподарської діяльності підприємства, установи, організації; бухгалтерського обліку; інтелектуальних, організаційних та службових можливостей злочинця

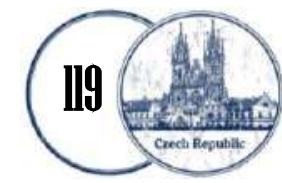


- службової особи.

Зазначено, що кожний зі способів вчинення незаконного обернення чужого майна на свою користь, вчинений 3 використанням службового становища має серійний характер, є вкрай небезпечним й замаскованим, тобто вміщує певну послідовність специфічних дій з підготовки, попередньої змови групи осіб та приховування протиправних дій, що призводить до вкрай великого рівня латентності.

Ключові слова: спосіб вчинення, службове становище, розтрата, заволодіння, привласнення, службова особа, юридична особа публічного права.

\title{
Roman Lev
}

Graduate student of the Department of Criminal Procedure and Criminology University of the State Fiscal Service of Ukraine Irpin, Ukraine, e-mail: zxcv79@meta.ua, https://orcid.org/0000-0001-9614-3978

\section{METHODS OF ILLEGAL TREATMENT OF OTHER PROPERTY TO YOUR USE BY USING OFFICE POSITION}

\begin{abstract}
The article examines one of the groups of methods of committing corruption crimes committed by officials of legal entities of public law, namely: illegal circulation of someone else's property in their favor, committed using their official position. The concept of a method of committing illegal circulation of someone else's property in one's favor through the use of an official position has been defined.

It is indicated that a feature of the methods of committing illegal circulation of someone else's property in their favor through the use of official position is the corrupt nature of such illegal acts and objects of criminal encroachments. It is also noted that the way of committing illegal circulation of someone else's property in his favor, which is committed by an official of public law using his official position, is influenced by the mental abilities of an official - a criminal, directly proportionally affecting the choice of means by the way of committing and concealing a crime. So, to ensure the possibility of committing a corruption crime of this category, an official needs to develop a certain technology of unlawful behavior, which can then be implemented personally or by a group of persons.

The classification of the ways of committing illegal circulation of someone else's property in their favor through the use of official position has been carried out. The forms and characteristic signs of the commission of crimes of this category, which depend on a number of circumstances, in particular: the general state of the
\end{abstract}


economy and its individual branches; spheres of economic activity where the crime is committed (trade, construction, coal industry, agriculture); the nature of the object of the encroachment; legal protection of areas of economic activity of an enterprise, institution, organization; features of the financial and economic activities of an enterprise, institution, organization; accounting; intellectual, organizational and service capabilities of a criminal - an official.

It is noted that each of the methods of committing illegal circulation of someone else's property in their favor, committed using an official position, is of a serial nature, extremely dangerous and disguised, contains a certain sequence of specific actions for the preparation, preliminary collusion of a group of persons and concealment of illegal actions, which leads to very high level of latency.

Keywords: method of commission, official position, embezzlement, seizure, misappropriation, official, legal entity of public law.

Постановка проблеми. У криміналістичному розумінні дані про спосіб вчинення злочину є одними з найважливіших, тому що саме спосіб вчинення злочину характеризується найбільшим обсягом криміналістично-значимої інформації, що дозволяє швидко й правильно зорієнтуватися в обставинах провадження, колі осіб, причетних до протиправної дії, висунути слідчі версії та визначити оптимальні шляхи їх перевірки, тому увага вчених-криміналістів до способу вчинення злочинів, як до одного 3 ключових елементів криміналістичної характеристики, приділяється постійно. Але, не зважаючи на загальний інтерес до даної категорії, способи вчинення злочинів, скоєних службовими особами юридичних осіб публічного права, як окремий об'єкт дослідження є малодослідженою сферою криміналістичної методики, оскільки більшість авторів не відокремлюють способи вчинення цієї категорії злочинів від інших корупційних злочинів. Також вважаємо, що класифікація способів вчинення досліджуваних злочинів постійно потребує удосконалення, тому що пов'язана 3 видозміною існуючих способів вчинення таких протиправних дій відповідно до сучасного стану розвитку економіки та корупційної злочинності зокрема.

Аналіз останніх досліджень та публікацій. Структуру, зміст та сутність способів вчинення злочинів, вчинених службовими особами юридичних осіб публічного права досліджували: В.М. Біленчук, В.Б. Вехов, А.Ф. Волобуєв, О.О. Дудоров, О.О. Житний, К.П. Задоя, Д.О. Калмиков, В.В. Луцик, В.О. Навроцький, М.І. Хавронюк, Р.М. Шехавцов.

Мета статті: дослідження сутності, особливості та специфіки виявлення способів вчинення незаконного обернення чужого майна на свою користь шляхом використання службового становища. Визначення класифікації способів вчинення даної категорії корупційних злочинів. 
Виклад основного матеріалу. Способи вчинення злочинів, скоєних службовими особами юридичних осіб публічного права, мають вагоме значення для розслідування цих протиправних діянь, оскільки вони безпосередньо пов'язані 3 іншими елементами їх криміналістичної характеристики та відіграють важливу роль як джерело фактичної інформації, що має організаційне й тактичне значення в процесі розслідування. Також вважаємо, що класифікація способів вчинення досліджуваних злочинів постійно потребує удосконалення, тому що пов'язана 3 видозміною існуючих способів вчинення таких протиправних дій відповідно до сучасного стану розвитку економіки та корупційної злочинності зокрема.

Спосіб вчинення злочинів, скоєних службовими особами юридичних осіб публічного права, доречно трактувати, як обумовлена об'єктивними та суб'єктивними факторами поведінка службової особи юридичної особи публічного права до, у момент і після вчинення злочину, яка спрямована на досягнення корисливого злочинного результату.

Вважаємо, що кожний спосіб вчинення злочинів, скоєних службовими особами юридичних осіб публічного права $є$ комплексом способів скоєння різної категорії злочинів, які перебувають у безпосередньому зв'язку між собою. Порушення такого зв'язку не приведе до досягнення наміченого злочинного результату. Тобто злочини, вчинені службовими особами юридичних осіб публічного права, мають певну технологію та особливості вчинення. Так, однією 3 груп способів вчинення злочинів, скоєних службовими особами юридичних осіб публічного права $є$ незаконне обернення чужого майна на свою користь, яке вчиняється 3 використанням службового становища.

Під способом вчинення незаконного обернення чужого майна на свою користь або користь третіх осіб, яке вчиняється 3 використанням службового становища, необхідно розуміти порушення службовою особою своїх адміністративно-господарських функцій для вилучення майна 3 чужого володіння шляхом привласнення, розтрати чи заволодіння ним безоплатно й назавжди.

У свою чергу, під зловживанням службовим становищем необхідно розуміти певні акти поведінки службової особи, які виражаються у: підготовці, підписанні наказів та розпоряджень, відповідно до яких змінюється юридичний статус майна; особистому вилученні майна; усних вказівках щодо передачі або переміщення майна; дозволі третім особам, які діють в інтересах винної службової особи, вилучати майно.

Також необхідно розуміти, що повноваження, якими наділена службова особа у зв'язку з реалізацією організаційно-розпорядчих функцій, не можуть бути безпосередньо використані для здійснення незаконного обернення чужого майна на свою користь, яке вчиняється 3 використанням свого 
службового становища, оскільки такі повноваження - щодо здійснення керівництвом певною галуззю, колективом, окремими працівниками - не включають можливості щодо управління або розпорядження чужим майном [1, с. 27].

Вважаємо за доцільне більш детально розглянути способи вчинення цієї групи злочинів на прикладі привласнення, розтрати або заволодіння чужим майном шляхом зловживання службовою особою своїм службовим становищем. У зв'язку з цим доречно способи вчинення зазначених злочинів поділити на три підгрупи, а саме:

1) способи вчинення злочинів, пов'язаних 3 привласненням, та розтрата майна шляхом зловживання службовим становищем;

2) способи вчинення злочинів, пов'язаних із заволодінням майном, шляхом зловживання службовим становищем.

Розглядаючи способи вчинення злочинів, пов'язаних 3 привласненням та розтратою майна, шляхом зловживання службовим становищем, потрібно визначити, що саме необхідно розуміти під «привласненням» та «розтратою» майна, визначити їх особливості.

Так, на думку В. О. Навроцького, яку ми підтримуємо, привласнення характеризується тим, що посягання здійснюється щодо майна, яким службова особа володіє правомірно, отримавши його у відання чи як ввірене. Тому вилучати майно в класичному розумінні для його привласнення немає потреби - відповідна службова особа юридичної особи публічного права й так ним володіє. Відомо, що найпоширенішим предметом аналізованих посягань $\epsilon$ грошові кошти, які перебувають на рахунках держави або окремих юридичних осіб, тому привласнення полягає у відданні розпоряджень про перерахування коштів на рахунки інших фізичних чи юридичних осіб. Привласнення у таких ситуаціях можна констатувати лише тоді, коли відбулося зняття коштів 3 рахунків потерпілого без належних на те підстав та їх зарахування на рахунок, який контролює злочинець - службова особа [1, с. 26]. Як бачимо, привласнення характеризується тим, що службова особа юридичної особи публічного права використовує свої повноваження для обернення ввіреного їй майна лише на свою користь.

Зі свого боку розтратою зазвичай вважають незаконне безоплатне відчуження, витрачання, використання службовою особою чужого майна, що на законних підставах було їй ввірене чи перебувало в іiі віданні (продаж, споживання, дарування, обмін, передача іншим особам тощо) [2, с. 7].

Розтрата, вчинена службовою особою юридичної особи публічного права, відрізняється від привласнення тим, що у разі розтрати майно відчужують і витрачають одразу, воно не перебуває певний час у незаконному володінні службової особи, а привласнення, вчинене службовою особою, передбачає наявність певного проміжку часу, впродовж якого службова особа незаконно

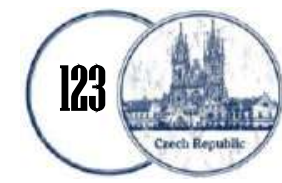


володіє майном, розпоряджається ним як власним. У разі привласнення майно (грошові кошти) перебуває у службової особи, а в разі розтрати майно вже використано (витрачено).

Проаналізувавши ці форми обернення чужого майна на свою користь або користь інших осіб шляхом зловживання своїм службовим становищем та визначивши їх особливості, можна перейти до розгляду безпосередньо традиційних способів вчинення злочинів, пов'язаних 3 привласненням та розтратою майна, шляхом зловживання службовим становищем. Отже, вони можуть проявлятись у таких формах:

- укладання фіктивних договорів на виконання робіт або надання послуг 3 подальшим вилученням коштів, перерахованих на рахунок оплати за невиконані роботи, ненадані послуги. Ці договори укладаються службовою особою юридичної особи публічного права, яка виконує адміністративногосподарські функції. У цьому випадку підприємствами, установами, організаціями, з якими підписуються свідомо фіктивні договори, виступають організації, зареєстровані за втраченими або викраденими документами громадян, товариства з обмеженою відповідальністю, фірми «одноденки»;

- внесення фальсифікованих (неправдивих) записів у первинні облікові (бухгалтерські) документи 3 метою подальшої фальсифікації кількісних та якісних показників під час прийняття виконаних робіт. Разом з тим цей спосіб характеризується тим, що обсяг виконаних робіт навмисно завищується, а грошові кошти списуються на підставі рахунків-фактур під приводом того, що роботи, зазначені у договорі, виконані повним обсягом. Фальсифіковані дані вносяться службовими особами юридичних осіб в акти приймання-передачі виконаних робіт (наданих послуг) та/або у довідки про вартість виконаних робіт і понесених витратах;

- списання грошових коштів юридичної особи публічного права у фонд заробітної плати. Сутність такого способу вчинення незаконного обернення чужого майна полягає в тому, що службова особа затверджує розрахункову відомість, табель на виплату заробітної плати працівникам, які є вигаданими («мертвими душами») або на підприємстві насправді не працюють, але про це знає тільки керівник. Типовими ознаками цього способу привласнення $\epsilon$ фальсифікація даних у розрахунковій відомості (підпис, прізвище, сума) або якщо заробітна плата перераховується на картковий рахунок, ії переведення у готівку для привласнення грошових коштів;

- перерахування коштів, отриманих від громадян і підприємств, установ, організацій різних форм власності, на рахунок оплати за надані житловокомунальні послуги. Як правило, зазначені розкрадання відбуваються шляхом штучного завищення тарифів оплати або завищення показників приладів обліку. Гроші, отримані від громадян, організацій, направляються не на рахунок оплати за послуги, отримані від постачальників, а перераховуються на 
рахунок службової особи або третіх осіб;

- завищення у звітних документах вартості придбаних товарів чи наданих послуг порівняно з фактичною вартістю, подальшим присвоєнням різниці між їх вартістю;

- безоплатне повернення рухомого майна державного підприємства іншому приватному підприємству.

Поряд 3 традиційними способами вчинення злочинів, пов'язаних 3 привласненням та розтратою майна, шляхом зловживання службовим становищем у сучасних умовах економічної моделі господарювання та бізнесу виникають й нові способи незаконного обернення майна на свою користь. Так, сьогодні особливу «популярність» має розкрадання службовою особою юридичної особи публічного права грошових коштів, які не $\epsilon$ коштами його підприємства, установи, організацій, а є коштами замовника, підрядника або інвестора. При цьому особливу небезпеку становлять привласнення або розтрата бюджетних коштів за державними замовленнями та тендерними закупівлями [3, с. 57]. Прикладом способу вчинення такої розтрати $\epsilon$ здійснення закупівлі на конкурсних торгах за завищеними цінами або закупівлі (поставці) обладнання, яке вже декілька разів продавалося та не $\epsilon$ новим.

Суспільна небезпека привласнень і розтрати майна, вчинене службовою особою юридичних осіб публічного права з використанням свого службового становища, у багато разів перевищує суспільну небезпеку традиційних розкрадань, оскільки досліджувана категорія злочинів завдає суттєвих збитків як державному, так і приватному секторам.

На нашу думку, доцільно розглянути способи скоєння злочинів першої підгрупи у різних галузях господарювання. Так, злочини, пов'язані 3 привласненням та розтратою майна, шляхом зловживання службовим становищем, здійснюються у сфері товарно-матеріального виробництва 3 використанням основних способів створення неврахованих надлишків, до яких можна віднести:

- використання недоброякісної або невідповідної прийнятим стандартам сировини й матеріалів, які занижують фактичну вартість продукції, що виготовляється, порівняно з вартістю, вказаною у документах;

- порушення технологічних режимів виготовлення продукції, спрямоване на зниження фактичної вартості продукції, порівняно з вартістю, вказаною у документах;

- виготовлення продукції, що не відповідає вимогам за якістю або кількістю використовуваних при цьому комплектуючих, також занижує іiі фактичну вартість.

Злочини, пов'язані 3 привласненням та розтратою майна, шляхом зловживання службовим становищем також здійснюються в оптовій та 
роздрібній торгівлі за допомогою створення неврахованих надлишків, а саме:

- фальсифікація даних щодо кількості або вартості продукції у прибуткових або видаткових накладних;

- завищення у документах закупівельних цін порівняно 3 реальною вартістю та з подальшим присвоєнням різниці;

- змішування сортів товару 3 подальшим присвоєнням різниці від продажу товарів нижчих сортів за цінами вищих сортів;

- списання частини вже реалізованої продукції на псування, усушку або утруску з присвоєнням різниці грошових коштів між вартістю фактично реалізованої продукції й вартістю продукції з урахуванням її списаної частини.

А ось незаконне обернення чужого майна на свою користь шляхом привласнення або розтрати у сфері приватизації здійснюється службовими особами юридичних осіб публічного права такими способами:

- заниження балансової вартості об’єктів, що приватизуються 3 подальшим присвоєнням різниці або 3 подальшим їх переведенням у свою власність або власність третіх осіб;

- поступове розкрадання основних й оборотних коштів 3 подальшим оголошенням підприємства банкрутом 3 метою приховання утвореної недостачі;

- вилучення грошових коштів юридичної особи публічного права 3 переведенням активів на свої рахунки (рахунки третіх осіб) або в офшорні зони й за кордон за допомогою використання легальних та нелегальних каналів.

Як бачимо, механізм обернення чужого майна на свою користь, вчинене службовою особою шляхом привласнення або розтрати, передбачає два етапи. Так, на першому етапі службова особа юридичної особи публічного права суб'єкт злочину створює невраховані надлишки (резерв) матеріальних цінностей, грошових коштів або інших об'єктів власності за допомогою їх незаконного списання або уцінки, ведення «подвійної бухгалтерії», внесення фіктивних даних до офіційних документів тощо.

На другому етапі службова особа - суб'єкт злочину потайки звертає створені надлишки на свою користь всупереч інтересам держави та громадян. На цьому етапі вчинення злочину службова особа отримує реальну можливість володіти та розпоряджатися оберненим майном як своїм власним.

Зазвичай злочини цієї категорії вчиняються організованими злочинними групами. При цьому до складу організованих злочинних груп можуть входити посадові особи контролюючих органів та підрозділів, включаючи ревізорів й аудиторів.

Розглянемо другу підгрупу способів вчинення незаконного обернення чужого майна на свою користь, яке вчиняється службовою особою 3 використанням свого службового становища, а саме заволодіння майном, 
шляхом зловживання службовим становищем. Зауважимо, що заволодіння майном, вчинене службовою особою юридичної особи публічного права шляхом зловживання своїм службовим становищем, передбачає вчинення дій щодо чужого майна, яке фізично не відокремлене від майна власника та не передане у фактичне володіння винної службової особи [1, с. 27].

Сутність заволодіння, вчиненого службовою особою юридичної особи публічного права, передбачає:

а) вилучення чужого майна $з$ володіння власника. Така протиправна дія зазвичай виконується за допомогою різноманітних операцій з вивезення або винесення майна; платіжних операціях щодо переведення коштів на інший рахунок. Специфіка окреслених дій вбачається в тому, що для їх вчинення службова особа юридичної особи публічного права використовує свої службові повноваження;

б) звернення чужого майна на свою користь, тобто заволодіння ним 3 метою використання як свого власного (включення чужого майна до сфери свого володіння).

Злочини, пов'язані із заволодінням майна, шляхом зловживання службовим становищем мають певний ряд способів вчинення, до яких можна віднести:

- здійснення закупівлі на конкурсних (тендерних) торгах матеріальних цінностей за кошти держави за завищеними цінами. Створення такої корупційної схеми у багатьох випадках відбувається за попередньою змовою групи осіб за участю службової особи юридичної особи публічного права щодо незаконного заволодіння державним майном;

- створення штучної заборгованості державного підприємства, установи, організації перед третіми особами за різними видами фіктивних правочинів. Цей спосіб заволодіння майном також вчиняється за попередньою змовою групи осіб;

- підроблення офіційних документів, які видає чи посвідчує державне підприємство, установа, організація, що надає права або звільняє від обов’язків з метою використання їх підроблювачем [2, с. 13];

- завищення обсягів виконаних робіт та застосування неправильних розцінок на роботи шляхом складення та видання завідомо неправдивого офіційного документа - акта приймання виконаних робіт [2, с. 13];

- укладення договорів про пайову участь у будівництві 3 подальшим заволодінням та привласненням грошових коштів, ввірених відповідно до умов вищевказаного договору.

Проаналізувавши способи вчинення незаконного обернення чужого майна на свою користь, яке вчиняється 3 використанням службового становища, можна виокремити ряд ознак, які свідчать про вчинення злочинів цієї категорії на державному підприємстві, установі, організації. До таких ознак віднесено: 
наявність виправлень та підчисток у бухгалтерських документах, актах ревізій та інвентаризацій, висновках аудиторів; виявлення необгрунтованих, недостовірних або неточних підрахунків у первинних облікових документах та документах аналітичного й синтетичного обліку юридичної особи публічного права, невідповідне збільшення доходів певних службових осіб; фальсифікація податкової звітності; збитковість господарської діяльності юридичної особи публічного права; укладання невигідних правочинів; надання фінансової допомоги (позики), яка призвела за собою появу великих боргів; укладання правочинів 3 відчуження майна юридичної особи публічного права без економічного i юридичного обгрунтування; укладення правочинів між зацікавленими особами; наявність відомостей про додатковий незадекларований дохід службових осіб; виконання великих, незвичайних або ускладнених операцій, особливо наприкінці звітного періоду; швидке та необгрунтоване зростання розміру активів організації або отримання незвично високого доходу, особливо порівняно з іншими організаціями в тій саме галузі чи сфері діяльності; вчинення великих експортних угод 3 фірмами, зареєстрованими в державах, що надають значні податкові пільги i не розкривають інформацію про підозрілі фінансові операції (офшори); досить складні й заплутані банківські розрахунки, що здійснюються через мережу філій одного або декількох афілійованих банків; використання у господарських та фінансових операціях численних посередників із сумнівною діловою репутацією; раптова заміна членів ревізійної комісії, аудиторів, консультантів 3 правових питань, осіб, відповідальних за складання бухгалтерської звітності.

Висновки. Підбиваючи підсумки, зазначимо, що цілий комплекс складних корупційних дій, пов'язаних зі зловживанням службовою особою своїми службовими повноваженнями, підробка офіційних документів та внесення до них фальсифікованих даних, використання складних технологічних процесів становлять загальну схему скоєння цього різновиду злочинів й більш детально розкриваються через механізм конкретних дій на кожному з етапів злочину.

\section{Лimepamypa:}

1. Дудоров О.О., Житний О.О., Задоя К.П., Калмиков Д.О., Луцик В.В., Навроцький B.О., Хавронюк М.І., Шехавцов Р.М. Корупційні схеми: їх кримінально-правова кваліфікація і досудове розслідування: практичний посібник / за ред. М. І. Хавронюка. К.: Москаленко О.М., 2019. 464 с.

2. Запотоцький А.П., Вознюк А.А., Кучменко С.В. Розслідування привласнення, розтрати майна або заволодіння ним шляхом зловживання службовим становищем у сфері будівництва: метод. рек. Київ: Нац. акад. внутр. справ, 2017. 78 с.

3. Волобуєв А.Ф. Механізм злочину та його зв'язок з концептуальними положеннями криміналістики: монографія. Кривий Ріг: Вид. Р.А. Козлов, 2019. 122 с.

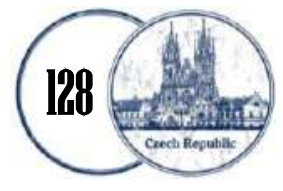


